\title{
Collaborative Activities in English Language Classes: Review of Secondary Schools in Lagos Metropolis, Nigeria
}

\author{
Gloria Nkechinyelu Ike-Nwafor \\ Department of General Studies, Federal College of Education (Technical) \\ Nigeria
}

\begin{abstract}
The study examines the need to reposition English language teaching and learning in Nigeria secondary schools using collaborative approach. It specifically brings to limelight the prevalence of the interactive nature of collaborative approach using selected public secondary schools in Yaba and Somolu Areas of Lagos State, Nigeria. A total of 180 students were sampled using stratified and simple random sampling techniques. Three research questions were answered. Research Instrument titled Collaborative Learning Approach Questionnaire (CLAQ) was used to collect relevant data for the study. The data collected were analyzed using mean and standard deviation (SD). The constructivist theory formed the theoretical framework for the study. Findings from the study revealed that teachers deemphasize collaborative approach as seen from respondents' response on the interactive activities employed in learning English as a second language. The teachers rigidly control the class activities, hence, learners were not wholly involved in the learning of the language as a result of lack of interaction with the material, with other students and with the teacher. Besides, male and female learners were observed not to differ in their view of collaborative approach of teaching. The study recommends a re-reorientation of teachers on collaborative approach where learners' voices are heard more than the teacher's voice. Teaching should be geared towards making students arrive at their own meaning, interact and share experience so that they will be in control of their learning. In addition, strategies adopted by the language teachers must take cognizance of this goal by being interactive, collaborative and participatory.
\end{abstract}

\section{Introduction}

The English language has been accorded with high status in the nation's educational system where it is a school subject as well as the medium of instruction from the last three (3) years of primary to the tertiary level. The overall aim is for every Nigerian citizen to possess a reasonable degree of competence and proficiency in English to be able to effectively shoulder national responsibilities in the task of nation building [2].

Education, in Nigeria, is considered synonymous with a good command of the language. According to
Banjo [3], if educated man is defined in Nigeria as one who has had at least secondary education then no Nigerian who speaks no English can be regarded as educated. English bestows some status on those who speak it fluently. It is no longer viewed as a temporarily borrowed language but has been accepted as part of our linguistic property by the majority of Nigerians. We often use it with creativity and ebullience, which spring from a confident sense of ownership, the fact that it is not our mother tongue notwithstanding. There is no better linguistic candidate for national integration, unity and identity than the English language. No Nigerian language can be considered as a useful tool for this herculean task [6]. Nigeria, a great country with its over 520 languages, no doubt, comprises several nations. For national cohesion, unity and social stability, however, the imperative of evolving a common (national) language is urgent. Unfortunately, none of the indigenous languages has been able to successfully harmonize or stabilize the country and our linguistic diversity rather than being a blessing has been regarded by many as a curse [7]. An attempt to politically resolve the lingering debate on Nigeria's national language led to the emergence of the WAZOBIA experiment and its failure to be acceptable by Nigerians. It is worthy to note that in spite of these numerous languages, only 65 have alphabets for writing and only 120 have texts written in them. This means that most of the Nigerian languages do not have the capacity to take up the challenges posed by proper language planning and engineering. It is easy to deduce why the English language carried the burden of the Nigeria language policy because it serves the needs of a multi-lingual country that is bereft of an indigenous official language. As laudable as the goal of the English language teaching is, it has its challenges and problems. In the views of Omodiaogbe cited in Eyisi [8]:

So long as the medium of instruction remains English and the language remains the bonafide official language of Nigeria, so long as most textbooks are written in English and so long as the language remains an international one and a veritable gateway to the understanding and mastering of science 
and technology, it will continue to be the primus interpares if not the umero uno.

Many writers have expressed dismay at the students' linguistic and communicative incompetence [4], [9]. No wonder, the seemingly fallen standard in our educational system is attributed primarily to our linguistic failure, since all education is education in language. The two important factors that affect the development of English in Nigeria and in any second language situation is the linguistic environments in Nigeria and the quality of teaching [5], [10]. The first factor is derived from the interference from the native languages and other languages in contact. Problems emanating from this factor are referred as interlingual problems. The second problem points to the teacher who is the pivot on which teaching and learning process depends for success. Whether the problem is inter-language or intra-language problem, an enormous responsibility revolves around the teachers of English in Nigeria. They must have the special training needed for adequate teaching of English. The radical structural differences between the English language and other Nigerian languages makes the teaching and learning of the language complex. The complexity can only be tackled if practical steps are taken to adopt effective skills, approach in the teaching of English in Nigeria. Based on the foregoing, the paper examines collaborative activities in teaching and learning of English as a second language (L2) in Nigeria and its effectiveness in active learning. It discusses the concept of collaborative approach: Its features and benefits. The paper examines the current practice and how it engages the learner in active processing and retention of information, resulting in greater mastery of subject matter.

The paper argues that corrective measures are needed in terms of active and interactive teaching approach to instill positive attitude, revive interest and enthusiasm, integrate motivation as well as enhance the quality of students' participation.

\section{Theoretical Framework}

The interactive strategies to be explored in this paper stem from the constructivist approach to learning. Constructivism is a view of learning based on the belief that knowledge is constructed by learners through an active mental process of development; learners are the builders and creators of meaning and knowledge. The theory draws on the developmental work of Piaget (1977) and Dewey (1916) whose theories of childhood development gave birth to constructivism. Their ideas were further developed by Vygotsky, while Ausubel and Brunner added new perspectives to constructivist learning theory and practice. Whereas Piaget is seen as a cognitive constructivist. Brunner is a social constructivist who highlights the importance of the social environment in learning. He asserts that learning is an active, social process in which students construct new ideas based on their current knowledge. Put in another way, learning is best if learners work in groups to share their perspectives, and in sharing, they bring their prior knowledge to bear on the task. Constructivist theorists postulate that learning is more effective when learners collaboratively and actively engage in the learning process instead of working in isolation. It is through interaction with people, environment and relating concept taught to what they already know that learners experience things, reflect on their experiences and by so doing they construct knowledge [17]. This is why the constructivists claim that knowledge is not given but gained through real experiences that have purpose and meaning to the learner. In using the constructivists' strategies, a lot of emphasis is placed on group interaction, collaboration and scaffolding which can be in the form of coaching, mentoring and modeling.

This is contrary to the traditional classroom in which students work in isolation and learning is achieved through repetition and drill with the teacher adhering strictly to the course outline and the textbook. Here learning occurs by passive response and rote learning. Teachers taught their pupils using the traditional method that encourage rigid class arrangement-learners sit in rows facing the teacher who is seen as a spring of knowledge, an omniscient narrator and rigidly controls all class activities (some teachers still use these outdated methods). The task of learning can be made more enjoyable and easier when students are given the opportunity to engage with new material as they learn; allowing them to process the information think through problems and arrive at their own meaning.

\section{Collaborative Language Teaching and Learning}

An approach is a set of corrective assumption about the nature of language and language learning, but does not involve procedure or provide any details about how such assumptions should translate into the classroom setting. Collaborative learning is an educational approach to teaching and learning that involves groups of students working together to solve a problem, complete a task or create a product. It is used as an umbrella term for a variety of approaches in education that involve joint intellectual effort by students or students and teachers by engaging individuals in interdependent learning activities. More specifically, collaborative learning is based on the model that knowledge can be created within a population, where members actively interact by sharing experiences and take on 
asymmetric roles. Collaborative learning as a strategy permits students and instructors to make good use of communicative forms.

Collaborative approach brings together philosophical perspectives and research traditions like: Humanistic education, Experiential learning and system-functional linguistic and psycholinguistically motivated classroom.

The above perspective points to how instruction happens in the classroom. An effective teacher need to embed these assumptions into planning and implementation of instructions. This teaching approach enhances maturity, experience and social communication in an academic environment while discouraging repetition, passivity and individuality. In their own assertion, McCafferty et al. [11], collaborative learning has interested practitioners of communicative language teaching because it offers tested classroom procedures such as face to face interaction between and among students, positive interdependence and development of social skills. It is on this note that Carrio-Pastor and Perry [12] remark that interdependence and mutual respect between the components of collaborative learning actively is essential to obtaining a coherent proposal. Students and teachers should become a coherent group that dialogues and negotiates in dynamic class. Collaborative language learning is based on the premise that cooperation is more effective for positive learning outcomes. In the views of Nunan (1993) as cited in Nnene, Ene and Chime [13] teachers, learners, researchers and curriculum specialists can collaborate for the purpose of the following:

Promoting philosophy of co-operation:

- Experimentation on alternative ways of organizing teaching and learning.

- Promoting philosophy of cooperation.

- Crating environment in an equitable way for learners and teachers.

- In co-operation of principles of learners' centeredness.

\section{Purpose of the Study}

The purpose of this research is:

1. To determine the extent to which collaborative approach is employed in language teaching and learning.

2. To assess the interactive strategies used in English language learning process.

3. To investigate if the strategies used engage students in active participation and exposure to more opportunities to use the target language.

\section{Research Questions}

1. To what extent is collaborative approach employed in English language learning?

2. What are those interactive strategies used in English language learning process?

3. Does collaborative approach engage you in active language learning and exposure to more opportunities?

\section{Methodology}

Three research questions were developed and answered in consonance with the purpose of the study. The study adopted a descriptive survey research design that made use of structured questionnaire items. The sample consists of 180 senior students drawn from six secondary schools in Yaba and Somolu Local Government Area of Lagos State. Stratified and simple random sampling technique were used. A 21-item questionnaire arranged on a 4 point rates scale of Always, Sometimes, Hardly, Never respectively and six item question Strongly agree, agree, disagree, strongly disagree were used. The instrument was facedvalidated by two seasoned lecturers in Measurement and Evaluation. The administration of the questionnaire was personally undertaken by the researcher who was able to retrieve all of them.

Mean and SD were used to answer the research questions. The cut-off mean was put at 2.50 .

\subsection{Population}

The subjects under study were Senior Secondary Schools (II \& III) students in Yaba and Somolu Local Government Area of Lagos State for 2019/2020 academic year.

\subsection{Samples and Sampling Technique}

The samples selected were 180 students (100 females \& 80 males) in Yaba and Somolu educational zones. In the first stage, stratified sampling technique was used in the selection of pupils according to gender (male \& female). Also, the second stage involved the use of simple random sampling approach in the selection of six schools from the educational zones.

\subsection{Active Learning Activities}

- A class discussion: This may be held in person or in an online environment. It is a good follow-up activity.

- A-think-pair-share: activity is when learners take a minute to ponder the previous lesson, later discuss it with one or more of their peers, finally to 
share it with the class as part of a formal discussion. Proposal by Frank Lyman of University of Maryland in 1981.

- A learning cell is an effective way for a pair of students to study and learn together. This was developed by Marcel Goldschmid of the Swiss Federal Institute of Technology in Lausanne.

- A short written exercise that is often used is the "one-minute paper. This is a good way to review materials and provide feedback.

- A collaborative learning group where you assign students in groups of 3-6 and they are given an assignment or task to work together.

- A student debate is an active way for students to learn because they allow students the chance to take a position and gather information to support.

- A reaction to a video is an active learning process because most students love to watch movies students understand what they are learning at the time in an alternative presentation mode.

- A small group discussion allows students to express themselves in the classroom.

just-in-three teaching is a sort of warm up exercise to encourage students thought on how learning goes.

- Game Based learning uses competitive exercises either kitting students against each other or through computer simulations.

- Gallery walk is a discussion technique that gets students out of their chairs and into a mode of active engagement. They walk together in small groups to share ideas and respond to meaningful questions, documents and problem-solving situations.

Role playing- each student takes the role of a person e.g. the effects of human activities on the world around us from the perspective of that person.

- Peer review/peer teaching. Students review and comment on materials written by their classmates.

- Problem-solving students use a variety of data to explore language questions.

\section{Results}

Research Question 1: To what extent is collaborative approach employed in English Language learning in Secondary Schools?

Observations from Table 1 show that two out of the six statements were above the criterion mean of 2.5. Statement 2 and 6 were the only statement above the criterion mean. This shows that to a low extent interactive approach was not employed in English Language learning in secondary schools.

Research Question 2: What are the interactive strategies you have experienced in class during English Language learning?

The analysis in Table 2 shows that group task project, think, pair share, brainstorming technique, group discussion/interactive session and Debate were scored by students as being used either "Sometimes" or "Always". However, the students observed that their teacher "Hardly" or "Never" used interactive strategies such as Reading Races, Game Based Learning, Gallery Walk, Running Diction, Milling, Jigsaw Task, Use of Diagrams/maps and other graphic organizers, Exciting Warmers as well as Role play. This shows that 9 out of the 15 strategies are not being used.

Research Question 3: Does collaborative approach engage you in active language learning and exposure to more opportunities?

Table 3 shows that most of the students are pleased with the several methods of collaborative learning. The students showed that they either Strongly Agree or Agree on the several techniques of collaborative learning.

\section{Findings}

i. The teacher gives the learners tasks and shared the roles each will play in preparation and presentation.

ii. The teacher does not engage the learners in brainstorming session and to share ideas in groups.

iii. The teacher does not allow peer and group feedback during English lesson.

iv. The teachers' talking time is more in class than the learners' talking time during English lesson.

$\mathrm{v}$. Interactive strategies such as reading races, game-based learning, gallery walk, running dictation, mingling and others are not being used. Nine out of the fifteen strategies listed are not being used.

vi. Most of the students are pleased with activities of collaborative learning since they agreed that they expose them to more opportunities.

\section{Conclusion and Recommendation}

The paper has discussed collaborative activities used in teaching and learning English language in selected secondary schools in Lagos, Nigeria. It has noted the current practice in relation to a number of collaborative activities that engage learners in active learning. A lot of poor results and linguistic incompetence have been recorded in the past years as a result of low proficiency in English. The paper advocates for strategies that will expose students to more avenues and opportunities to use the English language fluently and accurately through a process of cooperation, joint effort and sharing between students and teachers. Based on this, the paper recommends the following: 
Table 1. Descriptive Analysis of Interactive Approach by Teachers

\begin{tabular}{|c|l|c|c|c|c|c|c|c|c|c|c|}
\hline SN & Always & $\%$ & Sometimes & $\%$ & Hardly & $\%$ & Never & $\%$ & Mean & SD \\
\hline 1 & $\begin{array}{l}\text { The teacher in pairs/small/ } \\
\text { whole group of 3-6 makes } \\
\text { us share through oral } \\
\text { presentation and } \\
\text { interactive session. }\end{array}$ & 33 & 18 & 60 & 34 & 44 & 24 & 43 & 24 & 2.38 & 1.06 \\
\hline $\begin{array}{l}\text { The teacher does not give } \\
\text { us tasks through shared } \\
\text { roles preparation and } \\
\text { presentation. }\end{array}$ & 67 & 37 & 94 & 52 & 15 & 8 & 4 & 2 & 3.24 & 0.74 \\
\hline $\begin{array}{l}\text { The teacher engages us in } \\
\text { brainstorming session and } \\
\text { allows us to share ideas in } \\
\text { our groups. }\end{array}$ & 27 & 15 & 50 & 28 & 55 & 30 & 48 & 27 & 2.29 & 1.02 \\
\hline 4 & $\begin{array}{l}\text { The teacher allows peer } \\
\text { and group feedback during } \\
\text { English lesson. }\end{array}$ & 28 & 16 & 60 & 34 & 47 & 26 & 44 & 25 & 2.32 & 1.04 \\
\hline $\begin{array}{l}\text { The teacher encourages us } \\
\text { to communicate and speak } \\
\text { through task based and } \\
\text { role play. }\end{array}$ & 34 & 18 & 59 & 34 & 45 & 24 & 42 & 24 & 2.37 & 1.07 \\
\hline 6 & $\begin{array}{l}\text { The teacher talks more in } \\
\text { the class than us during } \\
\text { English lesson. }\end{array}$ & 66 & 37 & 78 & 43 & 25 & 14 & 11 & 6 & 3.15 & 0.88 \\
\hline
\end{tabular}

Table 2. Descriptive Analysis of Interactive Strategies in English Language Lessons

\begin{tabular}{|c|l|c|c|c|c|c|c|c|c|}
\hline SN & Statement & Always & \% & Sometimes & $\%$ & Hardly & $\%$ & Never & $\%$ \\
\hline 1 & Reading races & 15 & 8 & 30 & 17 & 45 & 25 & 90 & 50 \\
\hline 2 & group presentations & 11 & 6 & 84 & 47 & 32 & 18 & 53 & 29 \\
\hline & $\begin{array}{l}\text { games based learning (games and } \\
\text { competitions) }\end{array}$ & 11 & 6 & 27 & 15 & 48 & 27 & 94 & 52 \\
\hline 4 & group task project & 46 & 26 & 75 & 42 & 39 & 22 & 20 & 11 \\
\hline 5 & gallery walk & 7 & 4 & 12 & 7 & 60 & 33 & 101 & 56 \\
\hline 6 & running diction & 4 & 2 & 15 & 8 & 58 & 32 & 103 & 57 \\
\hline 7 & milling/mingling activities & 3 & 2 & 8 & 4 & 61 & 34 & 108 & 60 \\
\hline 8 & jigsaw task & 3 & 2 & 10 & 6 & 60 & 33 & 107 & 59 \\
\hline 9 & think, pair share & 49 & 27 & 66 & 37 & 40 & 22 & 25 & 14 \\
\hline 10 & brainstorming technique & 28 & 67 & 37 & 47 & 26 & 16 & 9 \\
\hline & $\begin{array}{l}\text { use of diagrams/maps and other graphic } \\
\text { organisers (to represent concepts, record } \\
\text { information and display language) }\end{array}$ & 10 & 6 & 40 & 22 & 57 & 32 & 73 & 41 \\
\hline & $\begin{array}{l}\text { exciting warmers/lead-ins used to reduce } \\
\text { boredom }\end{array}$ & 31 & 17 & 41 & 23 & 47 & 26 & 61 & 34 \\
\hline 13 & group discussion/interactive session & 53 & 29 & 76 & 42 & 36 & 20 & 15 & 8 \\
\hline 14 & Debate & 53 & 29 & 76 & 42 & 36 & 20 & 15 & 8 \\
\hline 15 & Role Play & 25 & 14 & 43 & 24 & 47 & 26 & 65 & 36 \\
\hline
\end{tabular}

Table 3. Descriptive Analysis of Collaborative Approach Engagement

\begin{tabular}{|c|l|c|c|c|c|c|c|c|c|}
\hline SN & Statement & SA & \% & A & \% & D & \% & SD & \% \\
\hline 1 & $\begin{array}{l}\text { I learn more when/work and share experience } \\
\text { with others }\end{array}$ & 82 & 46 & 74 & 41 & 15 & 8 & 9 & 5 \\
\hline & $\begin{array}{l}\text { Group activities/tasks makes more active, } \\
\text { confident and determined to learn and speak in a } \\
\text { safe environment. }\end{array}$ & 81 & 45 & 66 & 37 & 17 & 9 & 16 & 9 \\
\hline & $\begin{array}{l}\text { I learn more when the teacher assigns us roles, } \\
\text { provides variety of guidance explanation towards } \\
\text { completing tasks }\end{array}$ & 100 & 56 & 69 & 38 & 8 & 4 & 3 & 2 \\
\hline 4 & $\begin{array}{l}\text { The teacher gives me opportunity to interact and } \\
\text { practice language in and out of class. }\end{array}$ & 98 & 54 & 69 & 38 & 9 & 5 & 8 & 4 \\
\hline 5 & $\begin{array}{l}\text { Group discussion makes me alert and attentive in } \\
\text { class. }\end{array}$ & 89 & 49 & 77 & 43 & 12 & 7 & 2 & 1 \\
\hline 6 & $\begin{array}{l}\text { I learn more in English Language class when the } \\
\text { class is participatory and interactive. }\end{array}$ & 150 & 83 & 29 & 16 & 1 & 1 & 0 & 0 \\
\hline
\end{tabular}


i. Teachers of English should employ more collaborative activities that will actually engage learners in active interaction of the material given.

ii. Teachers of English should acquaint themselves with knowledge of these collaborative activities in order to improve their teaching competence and skills.

iii. Learners should be encouraged to process information and arrive at their own meaning, interact and share experience so that they will be in control of their learning and use language in varied life situations.

iv. Learners are engaged, motivated and active when they work together. To this end, teachers should organize activities / competitions that will enable them to co-operate and participate in such a way that communication and higher level thinking skills are developed.

\section{References}

[1] Arthur W. Chickering \& Zelda F. Gamson: Seven Principles for Good Practice (Pedagogy in Action) PIA website retrieved 3/10/2019. http://serc.carleton.edu >gallerywalk.

[2] Jegede, R. (2006). Issues in Language across Disciplines. NATECEP Journal of English and Communication Skills. 2:156-160

[3] Banjo, A. (1989). The status and roles of English as a second language. Nigeria, Educational Forum 12 (1): $1-4$

[4] Akere, F. (1995). Language in the Curriculum: An assessment of the role of English and other languages in the education delivery process in Nigeria. In Bamgbose et al (eds). New English: A West African Perspective Ibadan: Mosuro Publishers.

[5] Anyanwu, P.A. (2007). Language Learning in Otagbumegu, E.J. and B. Anyanwu (eds) Concepts and Issues in Language Studies. Owerri: Springfield, Publishers.

[6] Onuigbo, S.M. (2009). AND J.C. Eyisi (2009). English Language in Nigeria: Issues and Developments. Calabar: Paclen Publishers.

[7] Mekiliuwa, O.O. (2018). Language and Literary Studies as panacea for global economic recession, youth unemployment and insecurity. A lead paper presented at the 2018 International Conference of School of Languages, Adeniran Ogunsanya College of Education, Otto-Ijanikin, Lagos.
[8] Eyisi, J. (2015). Accuracy in the use of English 9th Inaugural Lecture of National Open University of Nigeria.

[9] Ike-Nwafor, G.N. (2013). Mass Failure in Public Examination: Has English Language Professional Practice failed the Nation? Journal of English Language. Teachers Association of Nigeria. 30: 5563.

[10] Nta, E.G., Egbe, G.B. and Oden, S.N. (2007). Optimizing Students' Performance in English through Quality Teacher Education. A paper presented at the 12th NATECEP National Conference Abuja.

[11] McCafferty, S.G., G.M. Jacobs \& A.C. DaSilva Iddings (2006). Cooperative learning and Second Language teaching. Cambridge: Cambridge University Press.

[12] Carrio-Pastor, M.L., Perry, D., (2010). The Collaborative Approach in Content and Language Integrated Learning. Berlin: Peter Lang.

[13] Nnene, B.G., Ene, F. and Chime, C.N. (2014). Collaborative Approach in Teaching and Learning of English as a Second Language. Journal of English Language Teachers Association of Nigeria 1(4), 123-134.

[14] Baldeh, F. (1990). Better English Language Teaching and Learning. Nsukka: Full Udu Publishing Company.

[15] Johnson D., Johnson, R. and Smith, K. (2000). Active Learning Co-operation in the College Classroom (2nd ed) Edin M.N. Interaction Books, Co.

[16] Bonwell, C.C. and Eison, J.A. (1991). ACTIVE Learning: Creating excitement in the Classroom: ACHE-ERIC Higher Education Report, Washington DC: School of Education and Development, George Washington University.

[17] Izuagba, A.O. and Nwigwe, N.V. (2013). Enhancing the Teaching and Learning of English Language using Interactive Strategies. In Ndimele, O.M. (et al Ed.) Language, Literature and Literacy in a Developing Nation. Port Harcourt: M \& J. Grand Orbit Communications: 231-239.

[18] Prince, M. (2004). Does Active Learning Works? A Review of the Research. Journal of Engineering Education. 93 (3), 223-231. 